\title{
Nietzsche se uitspraak God-is-dood' en die interpretasievoorștelle van Hans Küng en Jürgen Moltmann
}

\author{
A J Groenewald \& J H Koekemoer \\ Departement Dogmatiek-en Christelike Etiek (Afd A) \\ Universiteit van Pretoria
}

\begin{abstract}
Nietzsche's theorem 'God-is-dead' and the reading models of Hans Küng and Jürgen Moltmann

In this article the meaning and significance of Nietzsche's theorem 'Godis-dead' is examined. Through the reading models of Hans Kang and Jurgen Moltmann, an attempt is made to indicate that Nietzsche did not per se acknowledged or denied the existence of God. These reading models, although different, eliminate various theological misunderstandings and misinterpretations. This is important for the current theological debate.
\end{abstract}

\section{PROBLEEMSTELLING}

In dié artikel sal, in die lig van Nietzshe se uitspraak 'God is dood,' 'n poging aangewend word om deur middel van die interprestasie-modelle van Küng en Moltmann aan te toon dat Nietzsche nie per se die bestaan van God erken/ontken het nie. Soos Esterhuyse (1975) vanuit 'n filosofiese oogpunt aandag aan die relevansie van Nietzsche se stelling, sal daar in die artikel aandag gegee word aan dié twee teoloë se interpretasiemodelle om die stelling van Nietzsche relevant te maak vir die huidige teologiese debat. Inleidende opmerkings gee in kort die agtergrond van die problematiek van die Nietzsche-interpretasie in die lig van die negentiende-eeuse optimisme. Vervolgens wil die artikel Hans Küng in gesprek bring met Nietzsche oor sy filosofie teen die agtergrond van die negentiende-eeuse tydsgees. Vandaar wil uitgekom word by 'n interpretasiemodel waarmee Nietzsche se stelling 'God is dood' ondersoek kan word.

* Hierdie artikel is 'n verwerking van die resultate van die MDiv-sbripsie, ingedien en annvar as deel van die vereistes vir die MDiv-graad (1997), Departement Dogmatiek en Christelike Etiek, Fakulteit Teologie (Afd A), Universiteit van Pretoria, onder leiding van prof dr J H Koekemoer. 
Na die' gesprek tussen Nietzsche en Küng, word Jürgen Moltmann aan die woord gestel. Daar word aangetoon hoedat hy, in aansluiting by Hegel, dié 'God is dood' van Nietzsche in die hedendaagse tyd interpreteer. In die samevattende gedeelte word Moltmann en Küng met mekaar in gesprek gebring.

\section{INLEIDENDE OPMERKINGS}

Oor die jare heen is daar baie gespekuleer oor begrippe en die betekenis daarvan in Nietzsche se werke. 'n Mens kry byna die idee dat hy met 'n geheim graf toe is. D Bergoffen (1983:35) se dan ook: 'This is not to suggest, however, that distance has rendered Nietzsche's thought clear to us; it has not; for though we are closer to understanding Nietzsche, we are still quite far from comprehending him.'

Resente navorsers soos Esterhuyse het begin om Nietzsche se uitsprake te interpreteer in die lig van sy 'eie geskiedsfilosofiese beskouinge' (1975:69). Nietzsche het hom teen die vooruitgangsidee in die geskiedenis, soos wat dit deur denkers van sy tyd voorgehou is, verset. In die boek 'Vom Nutzen und Nachteil der Historie für das Leben' (1873) het hy hom besig gehou met die probleme wat die vooruitgangsgeloof van sy tyd gebring het. Volgens dié beskouing het die geskiedenis bewys dat die mens na hoër hoogtes ontwikkel. Die mens beskik dus inherent oor vooruitgangspotensiaal. God word geïdentifiseer met hierdie optimistiese ontwikkelingsgang van die geskiedenis. Hierdie vooruitgangspotensiaal is noodwendig en kan nie voorkom word nie.

In die beskouinge oor wat geskiedenis is, is deurgaans uitgegaan van die veronderstelling dat die mensheid as geheel voonuitgaan en steeds na hoër niveaus ontwikkel. Gewoonlik is die teenwoordige as nog 'n hoogtepunt in hierdie totale ontwikkelingsproses en daarom 'n vaste en sekere basis vir verdere ontplooiinge. In die meeste beskouinge in dié verband is veronderstel dat dit die wêreldrede is wat homself in stygende mate verwerklik via volkere en indiwidue heen. Die proses van vooruitgang was dus nie blote toeval nie. Dit was eerder redelik van aard en daarom noodwendig.

(Esterhuyse 1975:70)

Hegel het sy stempel op hierdie geskiedenisopvatting van Europa afgedruk. Hy het die Kantiaanse kategoriee van rede en kennis, wat slegs betrekking gehad het op die natuur, uitgebrei na die bestaansfeer of bestaanswêreld van die geskiedenis. Alles wat in die skepping gebeur is doelmatig en deel van die verloop van die geskiedenis. Daar is 
dan voc ruitgang in die verloop van die geskiedenis omdat alles in die geskiedenis op 'n teologiese ontwikkeling dui. 'Daarom is die wêreldgeskiedenis vir Hegel die enigste ware theodicee [sic]; die regverdiging van God self in en deur die geskiedenis .... [A]s regverdiging van God self in en deur die gebeure van die geskiedenis, is die geskiedenis redelik en sinvol' (Esterhuyse 1975:72).

\section{INLEIDING TOT DIE NIETZSCHE-INTERPRETASIE VAN HANS KüNG}

Hans Küng beskryf in sy boek, Theology for the Third Millennium, die periode vanaf Descartes tot by Whitehead (met Nietzsche wat ook binne dié kader val), as die modernistiese tydperk. 'n Simptoom van hierdie tyd was die sekulêre idee van vooruitgang wat uitgebrei is na elke aspek van die lewe as 'n tydelike model vir alle geskiedenis (Küng 1987:3).

Toe die geloofwaardigheid van die konfessionele denke in die sewentiende en agtiende eeu in die gedrang kom, het die moderne denke van die Aufklänng, soos vergestalt in die Duitse Idealisme en Romantiek, ' $n$ verandering in die teologiese beskouings gebring. Die moderne teologie het verweef geraak met die ervaringswêreld van die mens. Dit het gelei tot ' $n$ verandering in die verstaan van die mens, die gemeenskap, die wêreld en selfs God (Küng 1987:162).

Die moderne teologie is in 'n krisis gedompel deur die moderne wetenskapsbeskouings van denkers soos Kopernicus, Darwin en Einstein, die moderne filosofie van Descartes, Kant, Hegel, Heidegger en Whitehead, die moderne demokrasie, die moderne kritiek teen die godsdiens deur Feuerbach, Marx, Nietzsche en Freud, die moderne antropologie en sosiale wetenskap, die moderne eksegese soos die historiese kritiek deur Spinoza, Semler en Strauss en die moderne liberale bewegings. Die teologie was in 'n krisis omdat die mens en menslike ontwikkeling nou die middelpunt van belangstelling geword het in die plek van God. Die modeme teologie is vanuit die mens, vir die mens en in diens van die mens gebruik. Die vraag het ontstaan of daar hoegenaamd nog plek vir God in die wêreld was (Küng 1987:162).

Küng beskou Nietzsche as 'n denker binne hierdie moderne tydperk. In sy boek, Existiert Gotr?, bespreek hy denkers wat 'n belangrike rol in die tydperk gespeel het, onder andere Descartes en Hegel as eksponente van die moderne filosofie. Hierdie filosofie het tot 'n nuwe verstaan nie net van die rede, vryheid, die historiese en sosiale aard van die mens nie, maar ook die historisiteit en verwêreldliking van God gelei (Küng 1978:163).

Ander eksponente van die moderne tydperk wat ook aan die orde kom in Existiert Gott? is. Feuerbach, Marx, Freud en Nietzsche. Hulle het die godsdienste beskuldig daarvan dat hulle godsdiens misbruik vir die stabilisering en bereiking van sosiale ge- 
regtigheid in die sameleweing (Marx). Godsdiens is ook geblameer vir die 'vervreemding' van die mens (Feuerbach), vir die morele verval van die mens (Nietzsche) en vir die kinderlike agteruitgang van die mens (Freud) (Küng 1978:163).

Dit word vir ons duidelik dat Hans Küng al die moontlike elemente en eksponente van die moderne tydperk benut en verklaar om Nietzsche uit te wys as 'n denker in reaksie op die vooruitgangsidee as simptoom van die moderne tydperk.

\subsection{Die Nietzsche-interpretasie van Hans Küng}

Küng is van mening dat Nietzsche hom rig teen die teoloè van sy tyd, die ganse Duitse filosofie, asook die oppervlakkige ateisme van die natuurwetenskaplikes. Laasgenoemde staan volgens hom gevoelloos teenoor sake waaronder hulle self nie ly nie (Nietzsche 1968a: 172).

Nietzsche kon die idee van die vooruitgangsgeloof nie aanvaar nie. In hierdie denke word God bewys vanuit die vooruitgang van die mens in die geskiedenis, asof die menslike ras die ontwilkeling is van die betere, sterkere en hoogste goed. Dit is volgens Nietzsche 'n vals idee, omdat vooruitgang nie noodwendig met groei en ontwikkeling gepaard gaan nie. Nietzsche wys uit in hoeverre die Christelike geloof geskoei is op die idees van vooruitgang, groei en ontwikkeling. Wanneer ongelowiges tot inkeer kom en hulle skuld bely, vind daar vooruitgang plaas as hulle deur God vergewe word en hulle lewe voortsit as goeie en regverdige mense.

In aansluiting hierby wys Hans Küng op die belangrike invloed wat Charles Darwin gehad het op die negentiende-eeuse idee van vooruitgang. Darwin publiseer in 1859 sy boek On the Origin of Species by means of natural.selection, or the preservation of fawoured races in the struggle for life. Darwin, as 'n eksponent van die moderne wetenskap, het aangetoon dat die mens 'n plek het in die kosmos, die skepping en evolusie van die wêreld. Die mens wat so deel uitmaak van die skepping, is op 'n unieke wyse skepper en deelnemer (Küng 1978:163). Darwin het bewys dat daar genetiese ontwikkeling bestaan in mens- en dierspesies. Nietzsche het hom teen hierdie optimisme in die moderne wetenskapsbeskouing verset, alhoewel dit te betwyfel is of hy direkte kontak met Darwin gehad het.

Die moderne eksegese met die historiese kritiek as metode, was ook vir Nietzsche 'n steen des aanstoots. David Strauss, 'n bekende eksponent van hierdie rigting, het 'n beduidende invloed op Nietzsche se denke gehad. Strauss, die outeur van The life of Jesus en The old faith and the new, het onder invloed van die moderne eksegese die Christelike geloof binne 'n optimistiese, evolusionêre en meganistiese wêreldbeskouing georiënteer. Volgens Strauss het die Christelike geloof natuurwetenskaplik ontwikkel tot 'n nuwe geloof, naamlik die ongeloof. Die hemel is nou op die aarde met Jesus as 
eksentrieke figuur en die ewige lewe ' $n$ illusie of vergissing. Nietzsche het Strauss se skaamtelose, materialistiese optimisme afgewys. Volgens Nietzsche is hierdie optimisme, geskoei op vooruitgang, gevaarlik. Nietzsche wil nie van die heelal praat as die resultaat van natuurlike en ontwikkelende wette nie. Hy wil ook nie die heelal op 'n religieuse wyse verstaan as 'n metafisiese werklikheid en dit God noem nie. Strauss het nie die konsekwensies van sy beskouinge besef het nie. Hy het die moderne mens beroof van alle hoop vir ' $n$ lewe. hierna.

\subsection{Die kern van Nietzsche se filosofie}

Die kem van Nietzsche se filosofie is: 'Gott is todt [sic]! Gott bleibt todt [sic]! Und wir haben ihn getödtet [sic]! Wie trösten wir uns, die Mörder aller Mörder?' (Nietzsche 1968a:159). Hierdie uitspraak is volgens Küng aan drie redes te wyte, naamlik sy Christelike opvoeding, sy kritiese filologiese studie en die filosofie van Schopenhaver.

Friedrich Wilhelm Nietzsche is op 15 Oktober 1844 te Röcken naby Lützen in Sakse gebore. Nietzsche se pa is oorlede toe hy vyf jaar oud was. In sy skooljare kom hy in aanraking met die moderne eksegese en met die histories-kritiese metode as interpretasiemetode van die Nuwe Testament. Hierdie interpretasiemodel het die tradisionele waarhede van die Bybel bevraagteken. Die Bybel was nou 'n wetenskaplike objek van studie. Dit het in Nietzsche 'n stryd ontketen van geloof en ongeloof. Op twintigjarige ouderdom begin hy met sy studies aan die Universiteit van Bonn. Hy het aanvanklik in teologie belang gestel, maar Nietzsche was van mening: 'I took an interest in theology only in so far as I was attracted by the philological aspect of gospel criticism and the study of New Testament sources .... I still imagined at that time that history and historical research could provide a direct answer to certain religious and philosophical questions (Nietzsche 1954-65 Aangehaal in Küng, 1978:355).

In hierdie tyd lees hy die boek Leben-Jesu van Strauss, wat hom finaal laat breek met die Christelike geloof. Hy wend hom nou tot die filosofie van Schopenhauer. Hy sê dan ook: 'Der Atheismus war das, was mich zu Schopenhauer führte' (Nietzsche 1968b:316). Schopenhauer het nie in die vooruitgangsoptimisme van sy tyd gedeel nie. Volgens hom is daar agter elke gebeurtenis in die geskiedenis die drang om te oorleef. Die anname dat God buitendien in die verloop van die geskiedenis geopenbaar is, is onwaar. Egte filosofie vra nie na die oorsprong (waarvandaan), of die doel (waarheen), of die rede (waarom) van die wêreldgeskiedenis nie, maar na die wat. Dit word nou duidelik waar Nietzsche sy pessimisme jeens die vooruitgangsgeloof vandaan kry. Schopenhauer glo glad nie in die doelmatigheid van die geskiedenis nie, maar in die werklikheid van die hede, of anders gestel, in die wat daarvan. 
Ten spyte van al Hegel se argumente ten gunste van 'n optimistiese en ontwikkelende geskiedsbeskouing, is Schopenhauer daarvan oortuig dat die gang van die geskiedenis sonder enige doelmatigheid of planmatigheid is. Die gang van die geskiedenis en die verloop daarvan is sonder enige verborge betekenis. Schopenhauer sien dan ook die verlossing van die opgevoede mens in die bestudering van die kuns en musiek. Volgens hom kan Wagner se musiek die ideale plaasvervanger vir die opgevoede mens se godsdiens word. Nietzsche het dit sterk betwyfel, veral nadat hy sy vriendskap met Wagner beëindig het. Schopenhauer het besef dat hierdie verlossing kortstondig sou wees. Daarom sê hy dat die werklike, kwaliteitverlossing nie in die kuns aanwesig is nie, maar in die etiek van die barmhartige Samaritaan - dié van medelye en selfverloëning. (Dit verklaar sy latere asketisme).

Dit is dan ook juis teen hierdie etiek van selfverloëning en medelye van die Christendom (wat ook in die Boeddhisme bestaan), wat Nietzsche sy heftige aanval loods. Vir Schopenhauer bestaan daar geen doelmatigheid in die geskiedenis of ' $n$ hemelse doelwit vir die mensdom nie. Al wat vir die mensdom oorbly is die niksbeduidende, die mens se eie nietigheid.

\subsection{Nietzsche, die filosoof}

Nietzsche het in Richard Wagner 'n goeie plaasvervanger van Schopenhauer gevind, alhoewel hierdie vriendskap nie lank sou duur nie. In 1869 word Nietzsche op aanbeveling van sy leermeester Ritschl, sonder 'n doktorsgraad, by die Universiteit van Basel aangestel as professor in Grieks. Hier het hy vriende gemaak met die historici van sy dag, Jacob Burckhardt en Franz Overbeck. Na sy deelname aan die Frans-Pruisiese oorlog, het sy belangstelling vanaf filologie na filosofie verskuif. Vir Nietzsche het die pre-Sokratiese Griekeland, as 'n vervanger van die primitiewe Christendom, 'n model en norm vir ware menswees gebied. Nietzsche distansieer hom nou geheel en al van Schopenhauer. Hy voel dat geen godsdiens nog ooit 'n waarheid uitgespreek het nie. Waarheid (in die vorm van allegorie of dogma) kan nie deur godsdiens verkry word nie. Gedurende 1876 beëindig hy sy vriendskap met Wagner, omdat Wagner 'n bekeerling van die Christelike geloof geword het.

$\mathrm{Na}$ hierdie breuk met Wagner het Nietzsche se gesondheid vinnig agteruitgegaan. Dit veroorsaak sy bedanking in 1879 . Hierdie breuk het Nietzsche nog meer negatief gestem teenoor die kultuuroptimisme van sy tyd. Die hemel op die aarde, was vir hom onaanvaarbaar. Sy geloof in die moderne era was verpletter. Hy noem dit dan ook die tyd of era van verval. In 1881 word sy boek Die Morgenrote gepubliseer. Hierin het hy die moraal, voortspruitend uit die Christelike geloof, skerp aangeval. Volgens hom 
is die Christelike moraal die konsekwensie van 'n bepaalde werklikheidsverstaan. Nietzsche sien diê tipe moraal as minagting van en tén die lewe.

Nietzsche begin sy vyfde boek, Die frohliche Wissenschaft met die volgende woorde: 'Was es mit unserer Heiterkeit auf sich hat - Das gröBte neure Ereigniss, das 'Gott todt ist,' daß der Glaube an den christlichen Gott unglaub-würdich geworden ist - beginnt bereits seinen ersten Schatten über Europa zu werfen' (Nietzsche 1968c: 255). Die konsekwensies van hierdie denke gooi 'n skaduwee oor die ganse Europa. Dit word 'n probleem vir Europa wat die kultuur, Sokratiese filosofie en die Christendom bedreig. Daarom wil Nietzsche die werklike gevolge van hierdie denke uitspel. Hy sê dat die enigste ateisme wat bestaan in die wêreld, die geloof in die God van die werklikheid is, want dié God bestaan nie. Daarom is die gevolge van die werklikheid nie noodwendig goddelik nie.

God kan nie die gevangene van die geskiedenis wees nie. Die konsekwensies hiervan is natuurlik die vraag: Het die werklikheid enigsins $\sin$ en is daar werklik sprake van vooruitgang in die geskiedenis? Nietzsche probeer die gevolge van dié ateisme aandui deur dit te beskryf met die beeld van die mal man wat God met 'n lantern op die markplein soek. Hy rig die woorde van die mal man nie net op die teoloë nie, maar ook op die oppervlakkige ateiste, wat nie die werklikheid van die dood van God besef nie. Hulle besef en snap nie die betekenis daarvan nie. Die mensdom staan ook glad nie apaties teenoor hierdie gebeure nie. Die mense, en dan veral Nietzsche se tydgenote, het God vermoor met hulle valse aannames.

Küng verstaan die uitspraak 'God is dood' teologies. Nietzsche verwerp enige god, maar spesifiek die Christelike God. Hierdie uitspraak is nie deel van 'n woordspel nie, maar deel van 'n werklikheid, waar alles in sinloosheid gedompel is. Nihilisme is die enigste werklikheid wat oorbly. Nietzsche, soos ook vir Schopenhauer, ontbloot die ongoddelikheid van die werklikheid. Mense moet besef wat werklik waarheid is. Die dood van God beteken 'n algehele ineenstorting van alles wat bestaan, of 'n lewende leegheid waarvan die horison weggevee is. Hierop vra Nietzsche: 'Wohin bewegt sie sich nun? Wohin bewegen wir uns? Fort von allen Sonnen? Stürzen wir nicht fortwährend? Und rückwärts, seitwärts, vorwärts, nach allen Seiten' (Nietzsche 1968a:159).

Al wat oorbly is die nag van nihilisme, die leë niks en chaos. Nietzsche is bereid om die konsekwensies van die dood van God te aanvaar en die gevolge daarvan op hom te neem, as daar nie 'n God en vooruitgang van die geskiedenis is nie. Hy wil daarom die mense bewus maak van die moord op God. Die geloof in God en die implikasies van hierdie geloof moet oorkom word. God is dood, met 'n skadu wat oor die hele wêreld strek. Hierdie skadu moet verdwyn. Daarom bestaan daar vir Nietzsche nie 'n 
doelmatigheidsmotief in en van die skepping nie. Die verloop van die geskiedenis sal nie ontplooi tot hoër hoogtes nie. Die totale karakter van die wêreldgeskiedenis is in alle ewigheid chaos.

\subsection{Nietzsche se oplossing}

Die skadu van die geloof in God kan slegs verdwyn wanneer mense hulleself ophef tot 'n groter en hoër mensheid, naamlik die Übermensch, wat die aap sal cortref en so ook die mens. Die doel van ontwikkeling en vooruitgang in die geskiedenis is nie God en God se koninkryk nie, maar die Übermensch se heerskappy. Na die dood van God sal dié mens God se plek inneem. Die mens sal ook die implikasies van hierdie dood kan hanteer. Dit sal die nuwe tipe mens wees, die sterke en die wyse, die vernietiger en die liefdevolle. Daarom moet daar ter wille van 'n glansryke toekoms vir die mens, kritiek wees teen die bestaande waardes en stand van sake in die wêreld. Daar is egter ook 'n negatiewe taak vir die mensdom (Nietzsche 1968b:347).

\subsection{Nietzsche en moraliteit}

Nietzsche is gekant teen enige tipe moraal wat die lewe versaak en dit ontken. Wie sê dat God in die harte van mense kyk, ontken die vrye menslike wil en onderdruk die mens se polsslag vir lewe. Nietzsche is op soek na 'n gesonde tipe moraal wat spruit uit 'n passie vir die lewe. Die Christelike konsep van God as die God van die siekes en God as Gees, is vir hom onaanvaarbaar. God het die verskoning geword vir alles wat in die wêreld en geskiedenis gebeur. God is ook die leuen van hierdie wêreld en hierna. In God word die nietigheid of niksheid vergoddelik en die strewe na die niksheid verheerlik en geheilig. Die moral van die lewe, van die Ubermensch, is vir hom aanvaarbaar. Hierdie beskouing vorm die alternatief wat Nietzsche bied op die probleme van moraliteit.

Sy vertroue in die beskawing, kultuur, vooruitgang en moderniteit is geskend. Hy het in niks meer geglo nie. Die breuk met Richard en Cosima Wagner, het hom oortuig dat hy in ' $n$ tyd van onsekerheid, verval, vernietiging en nietigheid lewe. Die vraagteken van nihilisme het agter elkeen van sy uitsprake gehang. Nihilisme is die ontkenning van alles wat bestaan en die verwerping van alle stelsels. Daarmee word alles wat oud is, vernietig. Volgens Nietzsche is so 'n bestaan wanneer die hoogste waardes hulleself afwys en devalueer. Die doel ontbreek geheel en al.

Daarom het nihilisme 'n probleem met die vooruitgangsgeloof omdat dié geloof 'n doel nastreef - iets wat nie in die begripsapparatuur van die nihilisme bestaan nie. In die plek van morele waardes funksioneer natuurlike drifte en instinkte. Dit is natuur- 
like waardes geskoei op die lewensdrange. Godsdiens en die metafisika moet vervang word deur die leer van die 'Ewige Wederkeer' as die filosofie van die toekoms.

\section{6 'n Samevatting van Hans Küng se interpretasievoorstel}

Nietzsche was volgens Küng ' $n$ nihilis in die sin dat dit die resultaat van sy lewenservaring en nadenke geword het. Hy het as gevolg van sy lewensomstandighede gelewe sonder God of 'n tipe moraal. Küng wys ons daarop dat ons die uitdagings van nihilisme ernstig moet opneem en dat ons bereid sal moet wees om die konsekwensies hiervan te hanteer, ten spyte van die feit dat ons Nietzsche op baie aspekte kan kritiseer.

Die 'Ewige Wederkeer' was vir hom, as 'n mite, die vervanger van alle godsdienste. Dit is dan ook ironies dat juis Nietzsche, wat self onder die slae van die lewe gely het, hierdie teorie voorstaan en sodoende liefde vir die lewe propageer. Nietzsche het nooit ateisme regverdig nie, maar dit aanvaar as 'n gegewendheid. Hy wou nie die bestaan van God erken of ontken nie, maar op die psigologiese redes vir die geloof in God wys. Die mens glo in God, omdat hy na mag strewe en die gevoel van magteloosheid nie kan hanteer nie. Hierdie psigologiese redes vir die Christene se geloof in God maak die Christelike geloof vir Nietzsche onaanvaarbaar.

Das ist es nicht, was uns abscheidet, dass wir keinen Gott wiederfinden, weder in der Geschichte, noch in der Natur, - sondern dass wir, was als Gott verehrt wurde, nicht als 'göttlich', sondern als erbarmungswürdig, als absurd, als schädlich empfinden, nicht nur als Irrthum, sondern als Verbrechen am Leben ... Wir leugnen Gott als Gott ... wenn man uns diesen Gott der Christen bewiese, wir würden ihn noch weniger zu glauben wissen.

(Nietzsche 1968a:223)

As Nietzsche se kritiek teenoor die Christendom waar en korrek is, moet ons, volgens Küng, Nietzsche se anti-Christelikheid toegee. Sy kritiek was teen die lewensvreemde kerke as die grafte van God; teen die priesters wat teer op die skuldgevoelens van die mense en teen die Godsbeskouing van sy tyd. Hulle het God beskou as die kersvader van die swakkes, siekes en armes. Küng vra dan tereg:

Must it not be admitted that this critique of God is made for man's sake to protect human identity against a paralyzing knowledge, a petty moral supervision, an oppressive love of God? Did Nietzsche not get rid of 
God for man's sake: godlessness not as an end in itself but as a precaution against a belief in God that depreciates human existence.

(Küng 1978:408)

\subsection{Ten slotte}

Op 3 Januarie 1889 het Nietzsche op die skrale ouderdom van 45 jaar kranksinnig geword. Nadat hy 'n tyd lank in 'n gestig was, het sy ma hom tuis versorg. Na haar dood het sy suster na hom omgesien. Op 25 Augustus 1900 sterf Friedrich Wilhelm Nietzsche en word begrawe langs sy pa.

\section{DIE NIETZSCHE-INTERPRETASIE VAN JÜRGEN MOLTMANN}

\subsection{Inleiding}

Moltmann herinterpreteer Nietzsche se uitspraak 'God is dood' Christologies. 'The sufferings of Christ is the sufferings of God himself' (Moltmann 1991:74). Hy doen dit om die mensdom na twee wêreldoorloê weer hoop te gee nadat die mensdom se hoop op vooruitgang verlore gegaan het (Moltmann 1988:87). Hy herinterpreteer dié uitspraak van Nietzsche Christologies deur dit te begrond vanuit die dood en opstanding van Jesus Christus en sluit hier baie nou aan by Hegel (Moltmann 1965:155; 1980:36; Küng 1970:162). Hegel het die uitspraak 'God is dood' filosofies benader om die mensdom se aandag te vestig op die niksheid sonder God. Hy doen dit deur Goeie Vrydag 'n dieper betekenis te gee. Die historiese Goeie Vrydag is nie net die voorstelling van die godverlatenheid van Jesus Christus nie, maar ook die godverlatenheid van alles wat bestaan. 'Only then does resurrection, as a resurrection of the totality of being out of nothing, and only then does the birth of freedom and cheerfulness out of infinite pain, becomes a prospect necessary to all that is' (Moltmann 1965:169). Wanneer die moderne wêreld, wat in opstand is teen 'n outokratiese teistiese God, te staan kom voor die realiteite van die skaduwee wat oor Goeie Vrydag hang as die kelder van die niksheid wat alles omgeef, word dit 'n teologiese noodsaaklik dat hierdie wêreld gesien moet word as deel van 'n proses van God se openbaring aan die kruis en die opstanding as 'n realiteit.

From the theological standpoint one thing at least is unforgettably plain in Hegel - that the resurrection and the future of God must manifest themselves not only in the case of the god-forsakenness of the crucified Jesus, but also in that of the god-forsakenness of the world.

(Moltmann 1965:169) 
Moltmann stem saam met Küng dat Nietzsche met sy uitspraak bedoel het dat die god van die vooruitgang dood is omdat hoop in die negentiende ceu geassosieer is met die geskiedenis en die geskiedenis met die toekoms (Moltmann 1988:4). 'When in the nineteenth century people still felt certain that they knew who man was and therefore declared man to be the measure of all things, there came into being the anthropological criticism of religion as put forward by Feuerbach, Marx, Freud and Nietzsche' (Moltmann 1988:89).

\subsection{Moltmann se interpretasievoorstel}

Die enigste oplossing is gelee in die hoop van die opgestane gekruisigde God. 'Durch die Kunde von der Auferstehung des gekreuzigten Christus und in der Erfahrung seiner Geistesgegenwart kommt die Hoffnung auf universale Antwort in diesem Schrei nach Gott und damit auch die Hoffnung in die Welt, daß nicht die Tränen das Letzte sind' (Moltmann 1989a:234).

Die God in die stelling 'God is dood' is ook die opgestane gekruisigde God wat ons uit die geskiedenis leer ken het as die God van die belofte waarin ons glo en hoop. 'Das Kreuz Christi ist das Kreuz des von Gott auferweckten und zu Gott emhöhten Hernn' (Moltmann 1989a:235). Moltmann gee toe dat daar vooruitgang en hoop is in die geskiedenis, maar dat God nie daaruit afgelei kan word nie. "The world is not stabilized in eternal being, but is "held" in the "not yet being" of a history open towards the future' (Moltmann 1965:172). Wanneer 'n mens aan God in die geskiedenis dink lei dit altyd tot ateisme of teisme, terwyl die omgekeerde naamlik die geskiedenis in God die mens verby die dilemmas van ateïsme of teisme neem. "To "think of history in God" however, first means to understand humanity in the suffering and dying of Christ, and that means all humanity, with its dilemmas and its despairs' (Moltmann 1973:247). Hierdie siening van Moltmann sluit nou aan by Berdyaev se filosofie van die geskiedenis soos ons dit vind in Moltmann se boek The Trinity and the Kingdom of God. Dit waarteen Nietzsche in opstand gekom het, naamlik 'n teistiese onbetrokke god, bestaan nie meer nie. God het as Vader saam met sy Seun gely of soos Moltmann sê: 'the death of the Son is not the 'death of God,' but the beginning of that God event in which the life-giving spirit of love emerges from the death of the Son and the grief of the Father' (Moltmann 1976:252). Die smart van die Vader, die lyding van die Seun en die lewende hoop van die Heilige Gees was deel van Auschwitz.

Die geskiedenis het hom weer herhaal in God omdat God weer lyding en smart moes deurmaak met die gruwelhede van Auschwitz (Moltmann 1980:80-82; 1989b:64; 1991:74-75). 'The life of God within the Trinity cannot be conceived of as a closed cycle - the symbol of perfection and self-sufficiency' (Moltmann 1989b:55-56). Daarom bou Moltmann sy hele teologie rondom die beweging binne die Drie-Enige 
God. So beskryf hy die skepping as 'n daad van God die Vader wat die Seun en die Heilige Gees uitstuur, met die Seun wat die skepping verlos van sonde en die Heilige Gees 'who gives life to the world and allows it to participate in God's eternal life ...' (Moltmann 1985:97). Die Drie-Enige God is cok betrokke by die kerk op aarde. 'Through the experience of the live-giving Spirit in faith, in baptism, and in the fellowship of believers, people are integrated into the history of the Trinity' (Moltmann 1980:90).

\subsection{Die samevatting vañ Jürgen Moltmann}

Moltmann gee die mense na die verskrikking van die twee wêreldoorloè weer hoop, deurdat hy aan die mense die versekering gee dat God nie buite die wèreld aanwesig is nie, maar in hierdie wereld. Hy is nie net God nie, maar ook mens, nie net outokraties en wreed nie, maar ook die slagoffer van lyding en liefde. Hy is nie alleen God met ons en vir ons nie, maar ons is ook met God verenig deur sy lyding en sterwe (Moltmann 1989a:202). Hy is nie net die gekruisigde nie, maar ook die opgestane Here wat ons toekoms saam met God vir Ewig verseker het. 'Das Kreuz Christi steht in dieser Weltzeit von Gewalttat und Sünde - der Auferstandene lebt in der kommenden Weltzeit der neuen Schöpfung in Gerechtigkeit' (Moltmann 1989a:236). Ons hoop is nie net geleê in die gekruisigde en opgestane Here nie, maar ook in die verwagting van die komende Here, wanneer die Here weer sal kom met heerlikheid om te oordeel oor die lewendes en die dooies en dié wat glo saam met die Here te neem. Ons hoop is dus geleë in verlede (kruisiging), in die hede (opstanding) en in die toekoms (wederkoms) deur die gekruisigde, opgestane en komende God. In hierdie komende verwagting, wat reeds begin het met die opstanding van Christus uit die dood, is ons hoop en ewige toekoms verseker. 'Aus der Auferstehung Christi entfaltet die Freude kosmische und eschatologische Perspektiven auf die Erlösung des ganzen Kosmos. Einer Erlösung wozu? Im Fest der Ewigen Freude sollen alle Geschöpfe und die ganze Schöpfungsgemeinschaft Gott ihre Hymnen und Lobgesänge singen' (Moltmann 1995:367).

\section{SAMEVATTING EN KONKLUSIE}

Hans Küng en Jürgen Moltmann stem saam met mekaar dat Nietzsche nie per se bedoel het dat 'God' dood is nie. Volgens hulle het Nietzsche bedoel dat die god van die vooruitgang as 'n skepping van die moderne mens, dood is. Küng en Moltmann verskil egter oor die betekenis van Nietzsche se stelling vir ons huidige tyd. Küng is van mening dat dié stelling ons aandag opnuut vestig op die konsekwensies van 'n bestaan sonder God. 'n Lewe sonder enige rigting of hoop. Hy stem nie met Moltmann saam oor die Christelike herinterpretasie van die stelling 'God is dood' nie. 
But we need to be cautious: taught by the great Jewish-Christian tradition and with awareness of Hegel's problematical thought-model, we do well to be reserved towards such speculations about a 'suffering God,' a 'crucifici God,' even a 'death of God,' which are inspired more by Hegel than by the Bible.

(Küng 1992:85)

In teëstelling hiermee het Moltmann (1989a:235) die vraag of God kan ly met die dood van Christus in verband gebring. Moltmann bou trouens sy hele trinitariese toologie konsekwent rondom die opgestane, gekruisigde, komende Christus wat van die Vader uitgaan en deur die Gees die hoop is van 'n nuwe skepping om vir ewig en altyd by God te wees in volle vrede, vreugde en heerlikheid. Küng (1992:87) is van mening dat die hele Nuwe Testament daarvoor getuig dat dit nie God self (ho theos) was wat as die Vader op die kruis gehang het nie, maar 'God's Messiah and Christ, God's Image, Word and Son'. Paulus praat volgens hom van Christus wat in swakheid geknisig is en nie van God nie. Christus het deur sy opstanding deel geword van die Drie-Enige God wat ons deelagtig gemaak het aan die ewige lewe.

Indeed, only in this way, by the acceptance of this Son into God's eternal life, does God show himself to be near in solidarity with believers as he is with this only Son (and thus with all sons and daughters), even in extreme suffering, in forsakenness and in dying: as the one who shares in our grief and our suffering (merited or unmerited); as the one who is also affected by our suffering and by all injustice, compassionate in a hidden way and precisely in this way right to the end the infinitely gracious and powerful God.

(Küng 1992:88)

Hierdie interpretasiemodelle van Nietzsche se stelling 'God is dood' vestig tog ons aandag opnuut daarop dat God nooit aan enige vooruitgang of geskiedsbeskouing gekoppel kan word nie. God is die Gans-Andere wat doen en uitvoer wat God wil. Die god van die vooruitgang as 'n skepping van die mens, is inderdaad volgens Nietzsche soos geinterpreteer deur Küng en Moltmann, 'dood,' al verskil hulle interpretasiemodelle.

Dié interpretasiemodelle, alhoewel verskillend, soos wat in dié artikel aangetoon is, ruim verskeie teologiese misverstande en waninterpretasies uit die weg wat belang- 
rik is vir die huidige teologiese debat. Nietzsche se stelling 'God is dood' kry deur die interpretasiemodelle van Moltmann en Küng in die huidige konteks 'n nuwe teologiese betekenis wat relevant is vir elke teoloog.

\section{Literatuurverwysing}

Bergoffen, D B 1987. The eternal recurrence again. International Studies in Philosophy 15, 35-46.

Coli, G \& Montinari, M 1968. Nietzsche Werke: Kritische Gesamtausgabe. Berlin: De Gruyter.

Esterhuyse, W P 1975. Friedrich Wilhelm Nietzsche filosoof met 'n hamer. Kaapstad: Tafelberg Uitgewers.

Jonker, W D 1983. Die Gees van Christus. Pretoria: NG Kerkboekhandel.

Kaufmann, W 1968. Basic writings of Nietzsche. New York: U S Random House.

1971. The Portable Nietzsche. London: Chatto \& Windus.

Küng, H [1970] 1987. The incarnation of God, tr by J R Stephenson, New York: Crossroad.

- 1978. Existiert Gott? München: R Piper \& Co. Verlag.

- [1987] 1990. Theology for the third millennium, to by P Heinegg. New York: Anchor Books.

1992. Credo: The apostles' creed explained for today, tr by J Bowden. London: SCM Press.

Levy, O 1967. Thus spake Zarathustra, A book for all and none. London: George Allen \& Unwin Ltd.

Moltmann, J [1965] 1967. Theology of hope: On the ground and the implications of a Christian eschatology, tr by J Leitch. London: SCM.

- [1973] 1976. The crucified God. London: SCM.

- [1980] 1981. The Trinity and the kingdom of God: The doctrine of God, tr by M Kohl. London: SCM.

- 1985. God in creation: An ecological doctrine of creation, tr by $M$ Kohl. London: SCM.

1988. Theology today, tr by J Bowden. London: SCM.

1989a. Der Weg Jesu Christi: Christologie in messianischen. München: Kaiser Verlag.

[1989] 1992. The church in the power of the Spirit, tr by M Kohl. London: SCM.

1991. God: His \& Hers, tr by J Bowden. New York: Crossroad.

1995. Das Kommen Gottes: Christliche Eschatologie. Gütersloh: Gütersloher Verlagshaus. 
Nietzsche, F 1968a. Der Antichrist, in Nietzsche Werke VI 3, 172, 159, 223. 1968b. Ecce homo, in Niezssche Werke VI 3, 316, 347. 1968c. Die Fröhliche Wissenschaft, in Nietzsche Werke V 2, 255. 